\title{
Health and Welfare in the Factory and its Meaning for the Community.
}

By Miss A. M. Anderson, H.M. Principal Lady Inspector of Factories, Home Office.

"THERE is nothing you cannot ask and expect of the British worker. man or woman-they have ability for anything " said an employer to me, who was convalescent from severe illness, due to overwork throughout the war in his own Foundry.

The self-forgetful energy of production for the safety of the nation and the welfare of humanity suddenly brought together, into a co-ordinated movement for betterment of the personal life of the industrial worker, all sorts of isolated ideas experiments and efforts, that had been fitfully appearing ever since the early "part of the 19th century in England and France.

Constructive means of personal welfare and heaith of the individual worker, in the power-driven factory, have been variously attempted by many employers for years past; and the British nation in the Factory Acts, consolidated in 1901, laid the broad foundation for them in general rules for healthy and safe construction of the workplace, limitation of hours, pauses for meals and rest, and special regulations under medical guidance for prevention of the most obvious occupational diseases. Contributory to this foundation was the contemporary law relating to Public Health.

Only after the Great War was it generally realised how largely the personal welfare and health of manual labourers rests on their own co-operation, in understanding demand for and use of all the new means placed by development of science and advancing humanitarian and Christian ideals at the disposal of Industry, and how important it is to have trained, technical assistance in developing the full use of all these means in each workplace.

Food of the right kind and quantity at the right time, taken in proper surroundings, access to adequate washing appliances, rest and suitable recreation, these obviously alone, generally applied, could enable the workers to put forth the necessary sustained energy of such production as that of 1914 to 1918.

Exceptional stress, with exceptional migration and concentration of labour, led to all kinds of hastily devised means and agencies for securing these indispensable things. The need of going further, of increasing, if possible, the power of the normal worker to produce, of also adapting substituted, untrained and above all women's labour led to freshly concentrated application of scientific research as well as to exceptional social steps.

These gave us the Health of Munition Workers' Committee and all its studies, the more permanent Industrial Fatigue Research Board, the tem- 
porary Central Control Board (Liquor Traffic), the Hostels and Welfare Departments of the Ministry of Munitions and the Billetting Board, also permanent new powers to the Factory Department, Home Office, through the Act of 1916, to make, by Order of the Secretary of State, provisions for securing the welfare of workers or any class of them in any particular factory or workshop or for factories of any class, group or description. The subjects of welfare were provisionally enumerated as:- Arrangements for preparing ard heating and taking meals, supply of drinking water, supply of protective clothing, ambulance and first aid arrangements, supply and use of seats in workrooms, facilities for washing, accommodation for clothing, arrangements for supervision. Power was also taken to add to this list and it has been supplemented by the special Order, adding provision of restrooms as a subject of welfare. The Welfare Orders already number 12 , and preparation is being made, by official issue of all kinds of informing pamphlets on various aspects of welfare, for a far wider extension of means of health and welfare.

In fact, a new Science and Art of Labour is coming to light. And the psychological, psychophysical and physiological researches, into the capacity and limitations of the human motor, of nearly a generation of European thinkers now come into view in their highly practical bearings, with power to meet and reconcile the aims of the efficiency Engineer with his applications of "motion-study," the employer desiring the happiness as well as the production of his employed workers, and the workers seeking selfdetermination in the workplace.

Much must depend in method of securing health and welfare in the workplace on what are the general aims and kind of production, on whether the aim of quantity predominates, or whether the chief aim is to produce such an output in quantity and quality as will secure both general fitness in mind and body of the worker and the interest of the whole community in best production. No external means or conditions can ever replace the life and health-giving power of happiness in work itself for the worker, or what William Morris glowingly described under the name of his "fearless work and hopeful rest." * It may be assumed, however, in face of such new signs as the opening, under the joint ægis of the Boards of Trade and Education, of the British Institute of Industrial Art, for the encouragement of sound craft, quality and design in manufacture, the newer work of the Trade Boards in joint determination by employers and workers in the less organised industries of various conditions of work and wages, the means by Joint Industrial Councils of better self government for trades where organisation has been achieved, that the initiative, ideas and demands of the manual workers are going to have new scope and channels of great effect.

"See "Architecture, Industry and Wealth," pages 78-79. 
A skilled workman in a large factory where there is much high grade craft work, president of his Union and taking a leading part in the Joint Works' Committee and District Council, expressed to me the belief that they had within reach, if they could only see it, the power of achieving in cooperation with the Employers, no less than the re-creation of their work and surroundings.

The new position of Labour under the Peace Treaty, and Labour conventions and conferences following it, giving an integral part for the League of Nations to play in working out international social welfare standards for industrial life, gives a pledge that we have passed out of the stage where each country set up its own isolated standards of factory health and welfare. It gives hope that we shall avoid the past hindrances to advances in any country through subjection to the risks from prevalence of low standards in a neighbouring country. It reminds one of the saying attributed to Hippocrates in the Vth century B.C., that the art of healing is identical with the "love of man." The welfare of industrial workers is now openly acknowledged, in a way that cannot be misunderstood or pushed aside, to be no small part, owing to the many millions concerned, of the welfare of humanity.

The immense change in the field of vision, involving many communities besides our own, gives new meaning and interest to every practical detail for health, welfare and safety, every living experiment being made, whether by employers or employed workers, by the State or scientific workers, by civic or voluntary associations. All these agents, individually, and in co-operative action, are on the whole needed to work out in a truly healthful way the complex many-sided elements of welfare in industrial life and production.

In old, staple, and highly organised industries, fundamental to the whole economic life of the Commonwealth, e.g., cotton and woollen textiles, engineering, little seems ordinarily needed beyond on the one hand incursions of welfare Orders of the Secretary of State, on the other, joint action of the associated employers and workers. The State would break in on lethargic inherited customs of the trade, throwing by expert Inspectors new light on the gain of shilled management, of ambulance and first aid, of canteens and rest rooms, the most hygienic methods of supplying drinking water and organising cloakrooms and washing conveniences, good forms of protective clothing where needed. The employers and workers separately and jointly are beginning to find out the value of (and themselves push forward) skilled supervision and management of welfare measures in the factory. Other additional advantages, such as clubs, recreation and certain facilities for education, special hospitals and convalescent and holiday homes which " could not reasonably be required to be provided by the employer alone" have been in some instances voluntarily promoted by action and contributions of the workers. 
In other industries, for example, the migratory fish-curing industry, for which localised plant and buildings cannot be steadily in occupation and use throughout any extensive period of the year, and in which both workers and employers follow the material of the industry round the coast, highly special requirements for suitable welfarc arrangements are needed. The workers are less able to help in promoting requisite conditions and are peculiarly dependent on local voluntary and civic arrangements for lodging or housing, transport and special canteen, rest room and first aid organisation.

In industries, again, where materials or conditions of manufacture are liable to affect health adversely, or cause excessive fatigue, far greater importance attaches to professional and technical or scientific knowledge and understanding of the kind of welfare provisions likely to be most valuable. This appears in Orders with regard to ambulance and first aid in industries most liable to accident. In a highly special industry under elaborate special regulations for dangerous processes such as Potteries, however, where joint organisation of employers and workers had already grown up in conference with agents of the State, and self-inspection was given a prominent place before the Act of 1916, there are great possibilities of development of good welfare within the industry itself.

In trades where a high proportion of the workers are young persons, boys or girls, much more, naturally, has to be done by employers individually and collectively, under guidance or stimulation from the State and through special welfare trained management than by any primary initiative from the side of organised labour. Much has been done in many large works by excellent games and club organisation for boy-welfare, sometimes under ex-army officers.

For men and women workers alike, now in industry, a large measure of the growing amenities and humanisation of their conditions must be attributed to the substitution of women for men, in both munitions and non-munitions factories during the war. The novelty and the risks of their rapid, large-scale introduction, in workplaces where they had never before been thought of, led to willing co-operation of employers in hurrying on of fatigue prevention and labour-saving experiments, arrangements for proper feeding, washing, cloakroom and other personal welfare provisions, under some kind of technical supervision. The success in great measure of their work led, on their departure, to their leaving behind them a fruitful tradition as regards the value of welfare work.

The employers are far morc widely expecting and demanding trained welfare workers to help them in carrying out their new schemes for improved social conditions, and it is common, specially amongst the younger men returned from the war, to both speak of conditions directly conducive to 
the personal health and welfare of the workers as a foremost consideration in management, and also to treat such management as a matter for a specially trained supervisor.

In a factory in 'Scotland where a Workers' Council had secured from. the management a five-day week and an annual holiday with pay, of 14 days, excellent rest rooms with lending library and good educational facilities, the restaurant was staffed in turn by the workers. There, the experienced Welfare Supervisor, already a graduate in Arts, is studying for her Science degree while she carries on her work in the factory.

In a south country factory, where the main standards of factory hygiene were exceedingly well developed and special appliances for the newer welfare arrangements excellent, the well-trained Welfare Supervisor seemed to combine secretaryship service to all the many-sided workers' Committees with considerable responsibility for guiding the employer in carrying out general organisation of the factory. The arrangements for receiving and dealing with suggestions from workers for improving both factory methods. and social arrangements seemed to be very democratic and successful, and altogether one could not but be impressed with the community feeling of the place.

In a Lancashire warehouse where a Library Committee came into being three years ago, particularly for the benefit of numerous employees attending continuation classes at the cost of the firm, the Works' Committee was composed of the head buyer and heads of various sections. They reported to the firm the need of a welfare supervisor for the girls and the reply was they might select her, which they did. She became responsible to this committee, receives her directions from and reports to them, dealing with. welfare of boys and men as well as of the girls.

In the wide variety of experiments being made already, nothing strikes. one as more hopeful for the future than the spontaneous adaptation to the special needs of each workplace of the general idea of social welfare, particularly through democratic Works' Committees. The keynote of " service" has been firmly struck in many cases with much more than a simple echo. of the duty-to-serve spirit of 1914-1918.

In the civic recreation councils such as those of Birmingham and Leicester, the Joint Universities Council for Social Studies and Welfare Training, the Board for Religious Training.of Social Workers which unites all denominations, the various University diploma courses, the Welfare Workers' Institute, the Industrial Welfare Society, the Safety-First campaign, the work of all kinds of club organisations, not to speak of the long continued work of the Trade Unions, we can see voluntary help forthcoming in many and varied manifestations. Without such share of the community in it, of a living kind, the welfare movement could never endure and come to its full effect. 